\title{
A review on phytoconstituents of marine brown algae
}

\author{
Masuma M. Hakim and Illa C. Patel
}

\begin{abstract}
Background: From the last few years, the development and discovery of bioactive compounds and their potential properties from marine algae have been enhanced significantly. The coastal area is a huge storehouse for propitious algae. It has been the genuine reality that the consequence of marine algae as a source of different compounds is increasing.

Main body: Numerous advanced research devices are available for the discovery of synthetic compounds but still many researchers are working on natural bioactive compounds to discover their biological properties, which are useful to society. Marine algae are taking the preponderance of consideration from investigators owing to its phenomenon of biological activity like anti-cancer, anti-viral, cholesterol-reducing, and many more. A variety of compounds are collected from algae with specific purposes as they remain in an extremely ambitious and hard state; this condition is responsible for the synthesis of very particularly effective bioactive compounds. The present article is concentrating on the brown algae of the Gujarat coast, phlorotannins, polyphenol, phytosterol from brown algae, and their various applications. The main importance has been given to the secondary metabolites and various applications of marine brown algae.

Conclusion: From this review, it can be concluded that the prominent bioactive compounds from brown algae can cure many serious diseases. Besides, the potential biological activities of a special bioactive compound may represent the interest in the industry of pharmaceuticals, cosmeceutical, and functional foods.
\end{abstract}

Keywords: Marine Brown algae, Bioactive compound, Applications

\section{Background}

Seaweeds mean the varieties of macro algae available abundantly at sea or nearby areas which can be used commercially. Macroalgae/seaweeds are categorized as green algae (Chlorophyta), brown algae (Phaeophyta), and red algae (Rhodophyta) according to their pigmentation, nutritive, and chemical composition. Brown, red algae are mainly used in human nutrition as a source of many mineral elements, vitamins, protein, amino acids, etc. Brown algae are more abundant in a shallow rocky coastal area, especially when exposed at low tide. The vegetation of the algae provides an ideal habitat, food, and shelter for various animals. They act as epiphyte

\footnotetext{
* Correspondence: hakim.masuma1@gmail.com

Department of Life Sciences, Hemchandracharya North Gujarat University, Patan, Gujarat 384265, India
}

\section{Springer Open}

(c) The Author(s). 2020 Open Access This article is licensed under a Creative Commons Attribution 4.0 International License, which permits use, sharing, adaptation, distribution and reproduction in any medium or format, as long as you give appropriate credit to the original author(s) and the source, provide a link to the Creative Commons licence, and indicate if changes were made. The images or other third party material in this article are included in the article's Creative Commons licence, unless indicated otherwise in a credit line to the material. If material is not included in the article's Creative Commons licence and your intended use is not permitted by statutory regulation or exceeds the permitted use, you will need to obtain permission directly from the copyright holder. To view a copy of this licence, visit http://creativecommons.org/licenses/by/4.0/.

fauna. The holdfast of seaweeds binds the sediments together and prevents coastal erosion [1]. These are vast and various groups of organisms that play an important role in the marine ecosystem [2]. Marine algae have always aroused great interest in Asian culture as marine food sources [3]. Seaweeds come in an incredible variety of attractive shapes, color, and size, and are found in all the ocean of the world. In India, brown algae represent $0.2 \%$, red algae $27.0 \%$, and the other $72.8 \%$. About 206 algae are reported in the mangrove environment [4].

Marine algae live in a harsh condition that promotes the formation of oxidizing agents and secondary metabolites [5], and these types of compound have the responsibility for specific biological activity [6]. A variety of chemically active metabolites in their body, potentially help to protect themselves against other organisms. 
These active metabolites are also known as biogenic compounds, such as halogenated compounds, alcohols, aldehydes, and terpenoid, are produced by different species of marine micro and macro algae and have antibacterial, anti-algal, and anti-fungal properties that are effective in preventing biofouling and have other uses in therapeutics [1]. Sterols are the main nutritional component of seaweeds. Different species have different types of sterols, as green algae contain ucocholesterol, cholesterol, and $ß$-sitosterol while brown algae contain fucosterol, cholesterol, and brassicasterol. Red algae have desmosterol, cholesterol, sitosterol, fucosterol, and chalinasterol $[7,8]$. These properties make seaweeds more potential as a functional dietary supplement or for compound extraction. Seaweed extracts are rich in natural plant growth hormone and beneficial trace mineral. In algae extract, natural growth hormones like auxin, cytokines, and gibberellins are present in large quantities [9].

Brown algae were a huge and diverse class (Pheophyceae) of golden-brown algae varying from small filamentous form to large/giant complex seaweed. The brown algae contain the fucoxanthin pigment and different pheophycean tannins that are responsible for the characteristic greenish-brown color like the name indicated. Brown algae also provide a number of active components including unique secondary metabolites such as phlorotannin and many of them have specific biological activities that offer opportunities for their economical use [10].

The major orders found worldwide are fucales, dictyotales, and laminariales, these three orders are extensively used for bioactive compounds. More than 1140 secondary metabolites have been reported in phaeophyceae [11]. The different species of dictyotales group produce a wide range of bioactive secondary metabolites with broad defensive action against herbivores in the marine environment [12]. Among the three marine algae group, brown algae have an immense source of polysaccharide namely alginate and fucoidans, which reveals good biological activities such as anti-cancer, anti-viral, antiinflammatory, and anti-proliferative [1]. Bioactive compound fucosterol abundantly reported in brown algae and has so many biological activities such as anti-cancer [13], cholesterol-reducing [14], and anti-diabetic properties [15]. Brown algae are mainly used in different conditions such as hypothyroidism, cough, asthma, fatigue, stomach pain, hemorrhoids, and headache. It has been also used to promote weight loss and help in skincare [16]. There are various benefits of brown seaweed including reduced inflammation, blood thinning and cancer prevention [17]. Brown algae consist of a significant level of phenolic compound, a complex type of polysaccharide, extremely high biological activity, and more effective antioxidant compared to green and red algae [18]. Therefore, the objective of the present review is to focus on the distribution of brown algae along the coast of Gujarat, its bioactive compounds, and the bioactivity of isolated compound from it.

\section{Distribution of brown algae}

Eighty percent of the world's plant diversity has been recorded only in the aquatic environment, including over 150,000 species of algae found in intertidal zones and tropical waters of the seas, and it is the main source of natural products [19]. There are approximately 8000 species of marine macroalgae discovered on the world's coastlines, and they can exist up to $270 \mathrm{~m}$ deep. A total of 25 species of green algae, 90 species of brown algae, and 350 species of red algae are found in the global coastline area which is commercially important because of their biochemical content [20]. About 1500 species of brown algae has been identified worldwide [21]. Brown algae are observed in about 6, 91, 713 places around the world (Fig. 1).

There are about 265 genera and 2040 species belong to class Phaeophyta (Fig. 2), in which 95\% of those species are most widespread in cold to temperate waters. All data shown in the figure was accessed via GBIF on 21 October 2020. The GBIF (Global Biodiversity Information Facility) is an international network and research foundation supported by government authorities around the world and providing data on all types of life around the world.

The main sources of algae are found in the northwest, west-central and southwest Atlantic, and in the centraleast and southwest Pacific. India, with its long coastline, has vast marine resources along many open coasts and estuarine areas. Marine benthic algae of India were first published in 1970 with 20 species [22]. Based on the reports published in different journals, [23-25] prepared the updated checklist of algae. The checklist prepared in

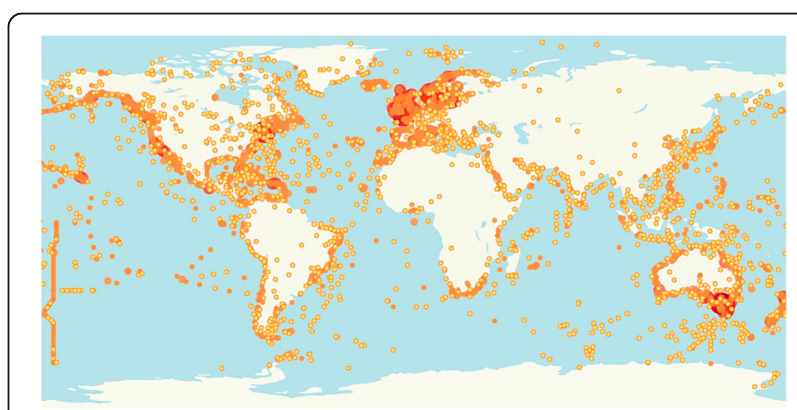

Fig. 1 A map published on GBIF, showing the worldwide occurance of brown algae. Source: GBIF (๑ OpenStreetMap contributors, $\odot$ OpenMapTiles,

GBIF) (https://www.gbif.org/occurrence/map?has_coordinate= true\&has_geospatial_issue=false\&taxon_key=7073593\&occurrence_ status=present) 


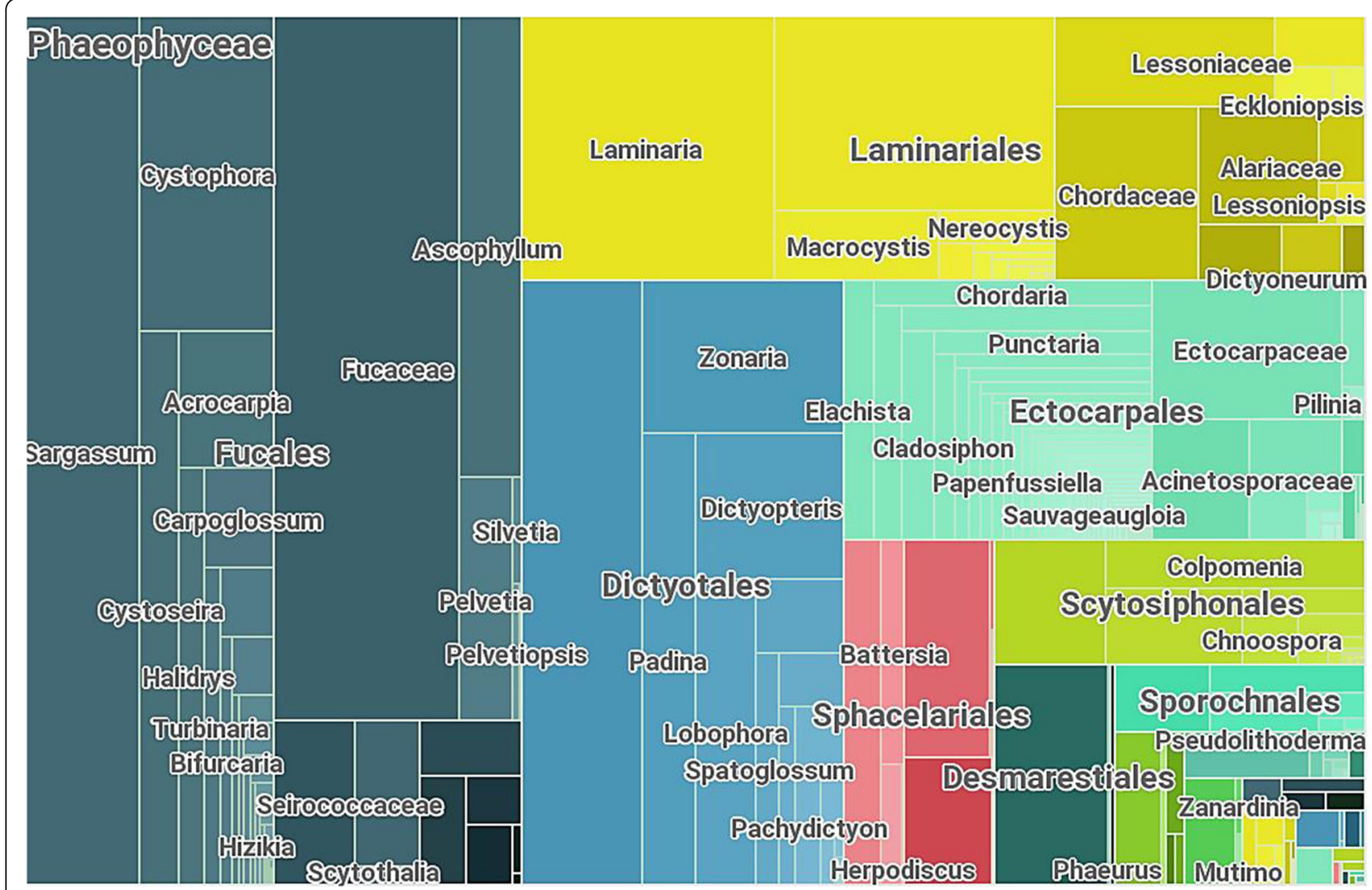

Fig. 2 Taxonomic distribution of major order and genus from phaeophyta group, record published by GBIF website. Source: GBIF (৫) OpenStreetMap contributors, @ OpenMapTiles,

GBIF) (https://www.gbif.org/occurrence/map?has_coordinate=true\&has_geospatial_issue=false\&taxon_key=7073593\&occurrence_status=present)

2001 comprises a total of 280 species from the Gujarat coast [24]. Seaweeds on the Indian coast consist of 814 species belonging to 217 genera. Out of these species, 216 species of Chlorophyta, 191 species of Phaeophyta, 217 species of Rhodophyta, and 3 species of Xanthophyta were recorded on Indian coasts among these 202 species were found only in Gujarat [26]. The coastline of Gujarat is made up of Deccan traps and tertiary stones and in places; there are fossilized forms of milliolite with limestone [27]. A list of brown algae recorded in the coastal area of Gujarat has been described in Table 1.

\section{Main text}

\section{Prominent secondary metabolites in brown algae}

Marine algae represent a good source of secondary metabolites/specialized metabolites. These specialized metabolites play important role in defense against pathogens. Phlorotannin, phytosterol, and polyphenol are prominent secondary metabolites groups that are found in brown algae. The variety of compounds within a particular group plays a vital role in many biological activities. Some prominent secondary metabolites from brown algae are as follows.

\section{Phlorotannins}

Polyphenols of marine algae are known as phlorotannins, which are observed in seaweeds and synthesized by the acetate-malonate pathway also known as polyketide pathway produced by the polymerization of phloroglucinol. Phlorotannins are extremely hydrophilic components with a wide range of molecular sizes between 126 $\mathrm{kDa}$ and $650 \mathrm{kDa}$ [28]. Among the green, brown, and red seaweeds, phlorotannins are normally isolated from the brown seaweed. This phytochemical has been isolated through chromatographic methods $[29,30]$. In addition, for characterizing the structure of compounds, nuclear magnetic resonance spectroscopy has been used [31, 32]. It has been recorded that members of laminariaceae are a rich source of phlorotannins compare to other seaweeds [33]. Phlorotannins have different biological activities such as anti-diabetic, antioxidant, anti-proliferative, anti-HIV, and skin protection, radioprotective, and anti-allergic activities [34].

Cystophora congesta have phlorotanin likes phloroglucinol triacetate, diphlorethol pentacetate, and triphloretholA-heptacetate [35]. The extract of Cystoseria showed good antioxidant and cytotoxic results, which can suggest that it can be effectively used in the synthesis of the cytotoxic 
Table 1 List of brown algae recorded at Gujarat coast [27]

\begin{tabular}{|c|c|c|}
\hline Sr. no. & Name of algae & Distribution \\
\hline 1. & Colpomenia sinuosa (Martens ex Roth) Derbes and solier & Okha, Shivrajpur, Veraval \\
\hline 2. & Cystoseria indica (Thivy and Doshi) Mairh & $\begin{array}{l}\text { Dwarka, Okha, Porbandar } \\
\text { Shivrajpur }\end{array}$ \\
\hline 3. & Cystoseria trinoidis (Forsskål) C. Agardh & Okha, Porbandar, Veraval \\
\hline 4. & Dictyopteris delicatula Lamouroux & Shivrajpur \\
\hline 5. & Dictyopteris acrostichoides (J. Agardh) Bornet & Okha, Shivrajpur \\
\hline 6. & Dictyopteris austalis (Sonder) Askenasy & $\begin{array}{l}\text { Adri, Dwarka, Okha, Porbandar } \\
\text { Shivrajpur, Veraval }\end{array}$ \\
\hline 7. & Dictyota bartayresiana Lamouroux & Adri \\
\hline 8. & Dictyota cervicornis Küzing & Kotada, Okha, Shivrajpur \\
\hline 9. & Dictyota ciliolate Küzing & Dwarka, Kotada, Shivrajpur \\
\hline 10. & Dictyota dichotoma (Hudson) Lamouroux & Okha, Shivrajpur, Veraval \\
\hline 11. & Dictyota pinnatifida Küzing & Kotda, Shivrajpur, Okha \\
\hline 12. & Dictyota serrata (Areschoug) Hyot & Okha \\
\hline 13. & Harmophysa cuneiformis (J. Gmelin) P. Silva & $\begin{array}{l}\text { Okha, Porbandar, Shivrajpur } \\
\text { Veraval, Vervala }\end{array}$ \\
\hline 14. & Hincksia mitchelliae (Harvey) Silva & Shivrajpur \\
\hline 15. & Hydroclathrus clathratus (C. Agardh) Howe & $\begin{array}{l}\text { Dwarka, Okha, Porbandar } \\
\text { Shivrajpur, Veraval, Vervala }\end{array}$ \\
\hline 16. & lyengaria stellata (Børgesen) Børgesen & $\begin{array}{l}\text { Dwarka, Okha, Porbandar } \\
\text { Shivrajpur, Veraval, Vervala }\end{array}$ \\
\hline 17. & Levringia boergesenii Kylin & Adri, Okha, Veraval \\
\hline 18. & Lobophora variegate (Lamouroux) Womersley ex Oliveria & $\begin{array}{l}\text { Adri, Okha, Porbandar, Shivrajpur } \\
\text { Veraval }\end{array}$ \\
\hline 19. & Padina tetrastromatica Hauck & Okha, Porbandar, Shivrajpur \\
\hline 20. & Padina boergesenii Allender and Kraft & Okha, Porbandar, Shivrajpur \\
\hline 21. & Padina boryana Thivy & Okha, Porbandar, Shivrajpur \\
\hline 22. & Rosenvingea intricate (J. Agardh) Børgesen & Shivrajpur \\
\hline 23. & Rosenvingea orientalis J. Agardh & Okha, Shivrajpur \\
\hline 24. & Sargassum cinctum J. Agardh & $\begin{array}{l}\text { Dwarka, Okha, Porbandar } \\
\text { Shivrajpur, Veraval }\end{array}$ \\
\hline 25. & Sargassum cinereum J. Agardh & $\begin{array}{l}\text { Dwarka, Okha, Porbandar } \\
\text { Shivrajpur, Veraval }\end{array}$ \\
\hline 26. & Sargassum johnstonii Setchell and Gardner & $\begin{array}{l}\text { Dwarka, Okha, Porbandar } \\
\text { Shivrajpur, Veraval }\end{array}$ \\
\hline 27. & Sargassum linearifolium (Turner) C. Agardh & $\begin{array}{l}\text { Dwarka, Okha, Porbandar } \\
\text { Shivrajpur, Veraval }\end{array}$ \\
\hline 28. & Sargassum plagiophyllum (Martens) J. Agardh & Okha, Porbandar, Shivrajpur \\
\hline 29. & Sargassum prismaticum Chauhan & Okha, Porbandar, Shivrajpur \\
\hline 30. & Sargassum swartzii C. Agardh & $\begin{array}{l}\text { Dwarka, Okha, Porbandar } \\
\text { Shivrajpur, Veraval }\end{array}$ \\
\hline 31. & Sargassum tenerrimum J. G. Agardh & $\begin{array}{l}\text { Dwarka, Okha, Porbandar } \\
\text { Shivrajpur, Veraval, Vervala }\end{array}$ \\
\hline 32. & Sargassum vulgare C. Agardh & $\begin{array}{l}\text { Okha, Porbandar, Shivrajpur } \\
\text { Veraval }\end{array}$ \\
\hline 33. & Spatoglossum asperum J. Agardh & $\begin{array}{l}\text { Adri, Okha, Porbandar, Shivrajpur } \\
\text { Veraval }\end{array}$ \\
\hline 34. & Stoechospermum marginatum (C. Agardh) Küzing & Adri, Kotda, Okha, Porbandar, Shivrajpur, Veraval \\
\hline 35. & Turbinaria ornata (Turner) J. Agardh & Okha, Porbandar \\
\hline
\end{tabular}


drug [36] and have bieckol, fucophloroethol, 7phloroeckol, and phlorofucofuroeckol compound [37]. Different species of Ecklonia revealed antioxidant, anticancer, and anti-diabetic properties due to the presence of different phlorotannin compounds like fucodiphlorethol G, phloroglucinol, eckol, dieckol, and phlorofucofuroeckol A [38-43]. Edible brown algae Eisenia arborea was used in folk medicine and showed anti-allergic properties owing to the phlorofucofuroeckol B compound [44]. Himanthalia elongate showed high anti-microbial and antioxidant activity, due to the presence of phloroglucinol [45]. Ishige okamurae showed the presence of diphloretohydroxycarmalol phlorotannin [46]. A list of phlorotannins in brown seaweeds has been recorded in Table 2 .

\section{Phytosterol}

Sterols are found in animals as well as plants. The sterols found in plants are known as phytosterol [47]. Phytosterol is a bioactive compound in marine algae, terrestrial, and marine plants. There are about 200 types of phytosterol have been found [48]. Stigmasterol and sitosterol are two common examples of phytosterols [49]. Mostly, brown seaweeds contain fucosterol and fucosterol derivatives [7]. These bioactive compounds are important because of the many beneficial health effects associated with them. The determination of phytosterols is generally performed by mass spectrometry or flame ionization detection [50].

The phytochemical compound fucosterol was first isolated by RP-HPLC method in Cystoseria foeniculacea and Dictyota ciliolate, and the fraction of compound also analyzed by NMR technique [51]. Bioactive compound fucosterol was responsible for anti-proliferative and cytotoxic properties in Padina sanctae-Crucis and Dictyota ciliolate [52]. HPLC analysis of brown algae Himanthalia elongate, Undaria pinnatifid, and Laminaria ochroleuca have showed the presence of steroid compounds like fucosterol and cholesterol [7]. By performing GC-MS analysis in brown algae, Hormophysa triquetra and Padina pavonica showed the presence of important phytosterols like fucosterol, stigmasterol, campesterol, and $\beta$-sitosterol [53]. Padina gymnospora and Sargassum angustifolium has great antioxidant activity and testified that they have a good source of fucosterol, brassicasterol, cholesterol, and stigmasterol by GC-MS analysis [54]. Sargassum asperifolium have important phytosterol compound like fucosterol, stigmasterol, saringosterone, and saringosterol [55], which gave good biological activities to it. The amount of phytol and fucosterol was quantified in edible brown algae Sargassum fusiforme [56]. A list of phytosterols reported in brown seaweeds has been recorded in Table 3.

\section{Polyphenols}

Polyphenols are a group of prominent secondary metabolites, which support the plant in structural development and protect the algae from biotic and abiotic stress condition [57]. Brown algal species have unique secondary metabolites namely as polyphenols and phlorotannin compound are a class of these polyphonic compound [58], this type of compound were formed under harsh condition and able to absorb UV-radiation and repair wound [59]. Polyphenols have great biological activities; these characters make brown algae used as major ingredients for cosmeceutical and nutraceutical products [60]. Polyphenols have shown therapeutic properties such as anti-oxidative, anti-bacterial, anti-cancer, anti-allergic, anti-diabetes, anti-aging, anti-inflammatory, and antiHIV activities [61, 62].

Different brown algae showed immense in vitro antioxidant activity and quantified the polyphenolic compound using the HPLC method [63]. It has been reported that Fucus species have gallic acid, protocatechuic acid, genistic, vanillic acid, and caffeic acid; Sargassum multicum have a good source of gallic acid, protocatechuic acid, genistic, vanillic acid, caffeic acid, and syringic; Saccharina latissima have gallic acid, protocatechuic acid, genistic, vanillic acid, and Laminaria

Table $\mathbf{2}$ List of phlorotannins reported in brown algae

\begin{tabular}{|c|c|c|c|}
\hline Sr. no. & Name of brown algae & Name of phlorotannins & References \\
\hline 1. & Cystophora congesta & Phloroglucinol triacetate, diphlorethol pentacetate, triphlorethol-A-heptacetate & [35] \\
\hline 2. & Cystoseria mudicaulis & Bieckol, fucophloroethol, 7-phloroeckol, and phlorofucofuroeckol & [37] \\
\hline 3. & Cystoseria tamariscifolia & Bieckol, fucophloroethol, 7-phloroeckol and phlorofucofuroeckol & \\
\hline 4. & Ecklonia bicyclis & Phloroglucinol, eckol & {$[38,39]$} \\
\hline 5. & Ecklonia cava & Fucodiphlorethol G, phloroglucinol, eckol, dieckol & {$[38,40,41]$} \\
\hline 6. & Ecklonia kurome & Phloroglucinol & [38] \\
\hline 7. & Ecklonia stolonifera & Eckol, dieckol, phlorofucofuroeckol A & {$[42,43]$} \\
\hline 8. & Eisenia arborea & Phlorofucofuroeckol B & {$[44]$} \\
\hline 9. & Himanthalia elongata & Phloroglucinol & [45] \\
\hline 10. & Ishige okamurae & Diphloretohydroxycarmalol & [46] \\
\hline
\end{tabular}


Table 3 List of phytosterols reported in brown algae

\begin{tabular}{|c|c|c|c|}
\hline Sr. no. & Name of brown algae & Name of phytosterol & References \\
\hline 1. & Cystoseria foeniculacea & Fucosterol & {$[51]$} \\
\hline 2. & Dictyota ciliolate & Fucosterol & {$[52]$} \\
\hline 3. & Himanthalia elongate & Fucosterol & {$[7]$} \\
\hline 4. & Hormophysa triquetra & Fucosterol, stigmasterol, campesterol & [53] \\
\hline 5. & Laminaria ochroleuca & Fucosterol, cholesterol & [7] \\
\hline 6. & Padina gymnospora & Fucosterol, brassicasterol, cholesterol, stigmasterol & {$[54]$} \\
\hline 7. & Padina pavonica & Fucosterol, $\beta$-sitosterol, campesterol & [53] \\
\hline 8. & Padina sanctae-crucis & Fucosterol & {$[52]$} \\
\hline 9. & Pelvetia spliquosa & Fucosterol & {$[51]$} \\
\hline 10. & Sargassum angustifolium & Fucosterol & {$[54]$} \\
\hline 11. & Sargassum asperifolium & Fucosterol, stigmasterol, saringosterone, saringosterol & {$[55]$} \\
\hline 12. & Sargassum fusiforme & Phytol, fucosterol & {$[56]$} \\
\hline 13. & Undaria pinnatifida & Fucosterol, cholesterol & {$[7]$} \\
\hline
\end{tabular}

digitata showed the presence of gallic acid, protocatechuic acid, genistic, vanillic acid, and caffeic acid. These phenolic compounds are responsible for the great antioxidant activity of algae [63]. Brown algae Himanthalia elongate confirmed the natural antioxidant compound like gallic acid, chlorogenic acid, caffeic acid, ferulic acid, and quercetin [45]. It has been testified that Padina boergesenii have important phenolic compound such as gallic acid, caffeic acid, rutin, quercetin, and ferulic acid which can be used as cancer chemopreventive agent [64]. HPLC profiling of Padina pavonica confirmed the presence of polyphenol compounds like kaempferol, tannic acid, caffeic acid, quercetin, and epigallocatechin, and FTIR analysis confirmed the presence of various groups like phenol, alkanes, alcohol, and aromatic compounds [65]. Different species of Sargassum have shown the major polyphenolic compound like gallic acid and Phydroxybenzoic acid, the presence of this compound was confirmed by RP-HPLC method [66]. A list of polyphenols reported in brown seaweeds has been recorded in Table 4.

\section{Biological importance of the isolated compound from the} brown algae

Diterpen bifurcadiol 76 has been isolated from Bifurcaria bifurcate; this diterpens shows cytotoxic activity against human tumor cell line; metaterpenoids from Sargassum tortile showed cytotoxic activity [67].

Table 4 List of Polyphenols reported in brown algae

\begin{tabular}{|c|c|c|c|}
\hline Sr. no. & Name of brown algae & Name of polyphenols & References \\
\hline 1. & Dictyota dichotoma & Gallic acid, protocatechuic acid, genistic, vanillic acid & [63] \\
\hline 2. & Fucus distichus & Gallic acid, protocatechuic acid, genistic, caffeic acid & \\
\hline 3. & Fucus serratus & Gallic acid, protocatechuic acid, genistic, vanillic acid, caffeic acid & \\
\hline 4. & Fucus spiralis & Gallic acid, protocatechuic acid, genistic, vanillic acid, caffeic acid & \\
\hline 5. & Fucus vesiculosus & Gallic acid, protocatechuic acid, genistic, vanillic acid, caffeic acid & \\
\hline 6. & Himanthalia elongate & Gallic acid, chlorogenic acid, caffeic acid, ferulic acid, quercetin & [45] \\
\hline 7. & Laminaria digitata & Gallic acid, protocatechuic acid, genistic, vanillic acid, caffeic acid & [63] \\
\hline 8. & Padina boergesenii & Gallic acid, caffic acid, rutin, quercetin, ferulic acid & [64] \\
\hline 9. & Padina pavonica & Kaempferol, tannic acid, caffeic acid, quercetin, epigallocatechin & [65] \\
\hline 10. & Saccharina latissima & Gallic acid, protocatechuic acid, genistic, vanillic acid & [63] \\
\hline 11. & Sargassum cinereum & Gallic acid, P-hydroxybenzoic acid & [66] \\
\hline 12. & Sargassum ilicifolium & P-hydroxybenzoic acid & [66] \\
\hline 13. & Sargassum multicum & Gallic acid, protocatechuic acid, genistic, vanillic acid, caffeic acid, syringic & [63] \\
\hline 14. & Sargassum swartzii & Gallic acid & [66] \\
\hline 15. & Sargassum tenerrimum & Gallic acid, P-hydroxybenzoic acid & [66] \\
\hline
\end{tabular}


Table $\mathbf{5}$ List of biological activity of isolated compound from brown algae

\begin{tabular}{|c|c|c|c|c|}
\hline $\begin{array}{l}\text { Sr. } \\
\text { no. }\end{array}$ & $\begin{array}{l}\text { Name of brown } \\
\text { algae }\end{array}$ & Isolated compound & Biological importance & Reference \\
\hline 1. & Bifurcaria bifurcata & Bifurcadiol 76 & \multirow[t]{2}{*}{ Cytotoxic activity } & \multirow[t]{2}{*}{ [67] } \\
\hline 2. & Sargassum tortile & Meroterpenoids, Sargol, Sargol-I And Sargol-LI & & \\
\hline 3. & Notheia anomala & Tetrahydrofuran & Nematocidal activity & [68] \\
\hline 4. & $\begin{array}{l}\text { Cystoseira } \\
\text { tamariscifolia }\end{array}$ & Meroditerpenoid & $\begin{array}{l}\text { Anti-fungal activity against pathogenic fungi; } \\
\text { anti-bacterial activity }\end{array}$ & [69] \\
\hline 5. & Lobophora variegata & Lopophorins A 142 And B 143 & Anti-inflammatory activity & \multirow[t]{2}{*}{ [67] } \\
\hline 6. & Dictyota dichotoma & Dictyol J 146, Diterpenes, Dictyolactone & Algicidal activity & \\
\hline 7. & Ecklonia stolonifera & $\begin{array}{l}\text { Phloroglucinol, Eckstolonol, Eckol, Phlorofucofuroeckol } \\
\text { A }\end{array}$ & Hepatoprotective agents & [70] \\
\hline 8. & Dictyota pfaffi & Dollabelladiene & Anti-viral activity. & [67] \\
\hline 9. & Sargassum thunbergii & Tetraprenyltoluquinols, Thunbergols & \multirow{3}{*}{$\begin{array}{l}\text { Free radical scavenger and antioxidant } \\
\text { activities. }\end{array}$} & \\
\hline 10. & Ecklonia cava & Fucodiphlorethol G 192 & & \\
\hline 11. & Taonia atomaria & Taondiol, isoepitaondiol, stypodiol, stypoldione, sargaol & & \\
\hline 12. & Pelvetia siliquosa & Fucosterol & $\begin{array}{l}\text { Anti-diabetic priciciple from Pelvetia } \\
\text { siliquosa }\end{array}$ & [71] \\
\hline 13. & Dilophus okamurae & Dictyterepenoids A 194 and B 195 & $\begin{array}{l}\text { Anti-feedent } \\
\text { activity against young abalone }\end{array}$ & [72] \\
\hline 14. & Eisenia arborea & Phlorofucofuroeckol-B & Anti-allergy activity & [73] \\
\hline 15. & Ecklonia stolonifera & Eckol, phlorofucofuroeckol A, dieckol & Anti-hypertensive activity & [74] \\
\hline
\end{tabular}

Tetrahydrofuran from Notheia anomala inhibit the larval developments of parasitic nematodes [68]. Cystoseira tamariscifolia have metaterpenoidmethoxybifurcarenone 138 which possesses anti-fungal and anti-bacterial activity [69]. Lopophorins from Lobophora variegate showed anti-inflammatory activity. Diterpens-Dictyol J 146, Dictyolactone, and Sanadaol were isolated from Dictyota dichotoma; these compounds have algicidal activity [67]. Phloroglucinol and its derivatives from Ecklonia stolonifera act as hepatoprotective agents [70]. Isolated compound Dollabelladiene derivative 147 from Dictyota pfaffi showed in vitro anti-HSV-1 activity. Bioactive compounds like tetraprenyltoluquinols, thunbergols, fucodiphlorethol G 192, taondiol, isoepitaondiol, stypodiol, stypoldione, and sargaol which has been isolated from Sargassum thunbergii, Ecklonia cava, and Taonia atomaria posseses high free radical scavenger and antioxidant activities due to its bioactive compound [67]. Brown alga Pelvetia siliquosa showed anti-diabitic activity due to phytosterol like fucosterol [71]. Diterpenoids from Dilophus okamurae displayed anti-feedent activity [72]. Phlorofucofuroeckol$\mathrm{B}$ has been isolated from Eisenia arborea which showed anti-allergic properties [73]. Different types of phlorotannin isolated from Ecklonia stolonifera have anti-hypertensive activity (inhibitory activity against angiotensin-converting enzyme) [74] Table 5.

It has been recorded that, compared to green and red algae, brown algae have shown higher anti-microbial activity against different aquaculture pathogens [75]. A variety of bioactive compounds are synthesized by marine algae, subjected to tolerate environmental changes such as radiation, stress, water pressure, and high temperature [76]. Brown algae contained polysaccharides such as laminarin, alginic acid fucoidan, and sargassan [76], and this type of algal polysaccharides showed anti-cancer activity [77]. Phlorotanins are a type of tannin, belongs to the group of polyphenolic compounds, which has usually found in brown algae. These polyphenols inhibit colon cancer cells [78]. Terpenes are also recorded in brown algae. In terpenes, halogenated monoterpenes are important in different biological activities. Isolated halogenated monoterpenes showed important anti-proliferative activity [79] (Fig. 3).

It has been testified that brown seaweeds are a good source of sterols like fucosterol and desmosterol, and it has been recorded that this type of sterols decreases the level of cholesterol, free triglyceride in the liver [80]. Phloroglucinol is polyphenolic compound, which showed different biological activity such as anti-oxidant, anti-diabetic, anti-inflammatory, anti-allergic, and antiHIV [81-86]. The phlorotannins (phloroglucinol, eckol and diekol) from brown algae E. cava have been used in cosmeceuticals products [80]. Edible brown algae Eisenia arborea have phlorofucofuroeckol-B, shown strong antioxidant activity, it suggests a potential use in antiallergic drug preparations [44]. The sulfated polysaccharides from Padina tetrastomatica have been used in 


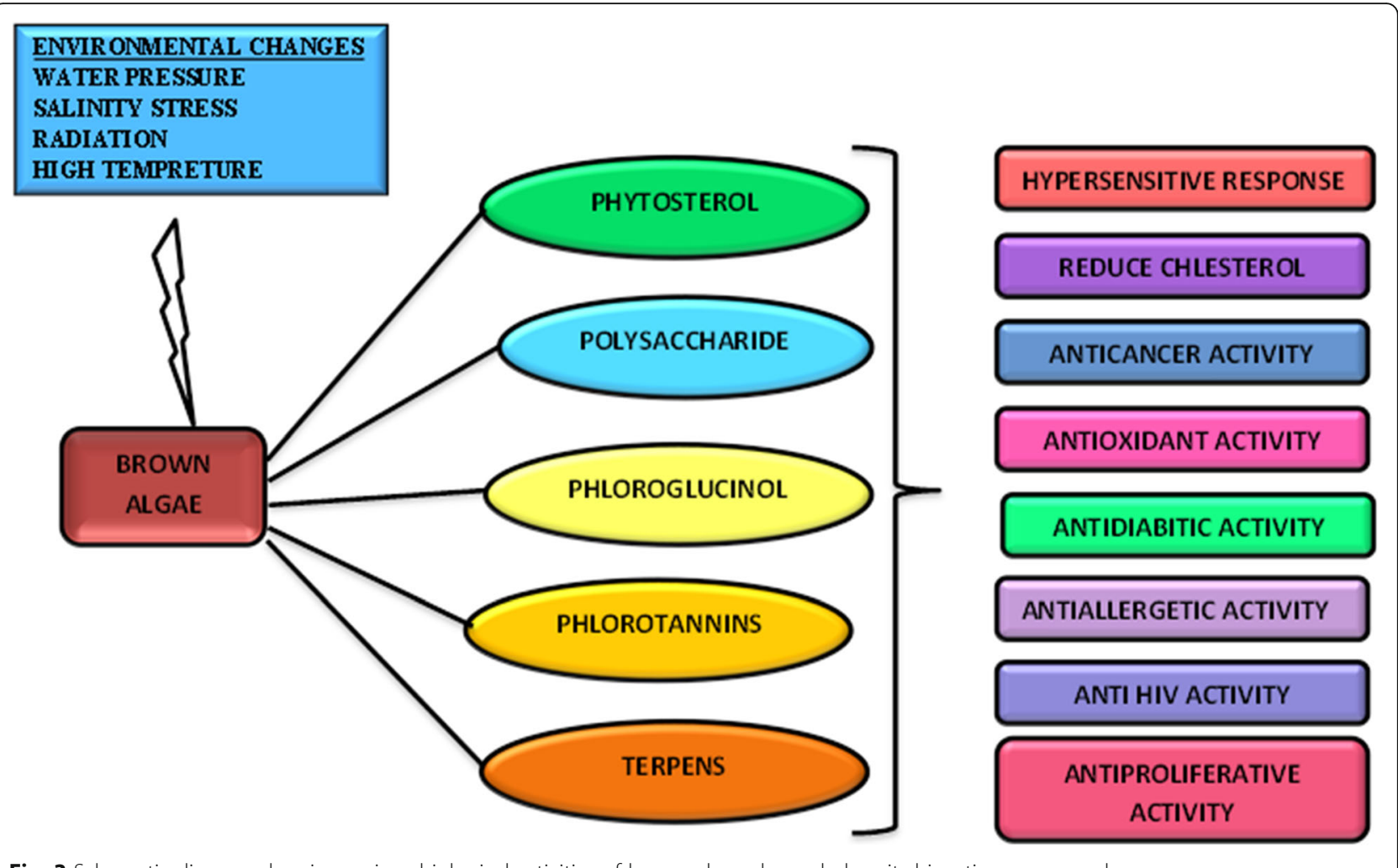

Fig. 3 Schematic diagram showing various biological activities of brown algae depended on its bioactive compounds

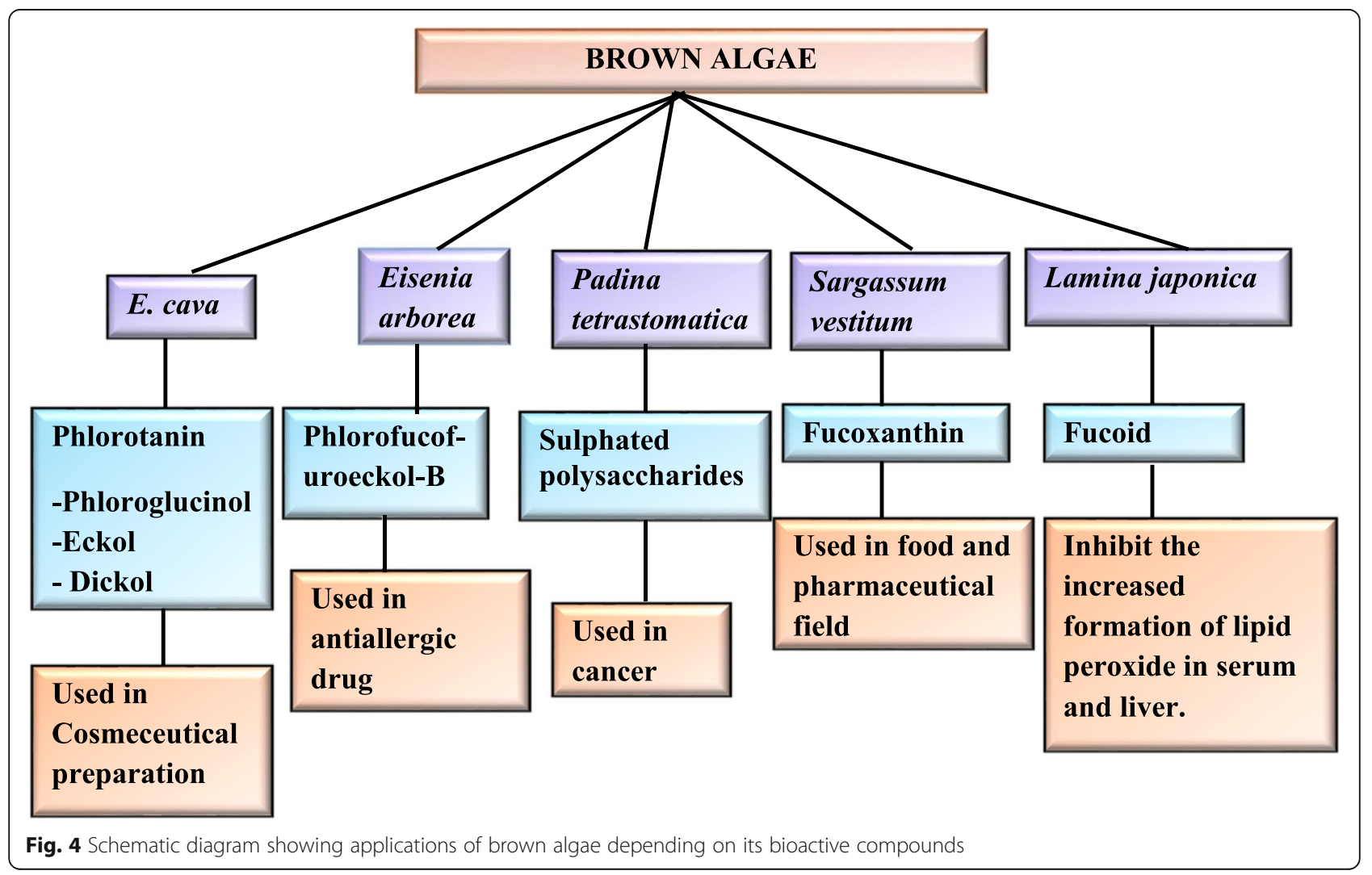


cancer treatment because it showed strong antioxidant and anti-mitotic activity [87]. A brown algae Sargassum vestitum has active compound fucoxanthin which showed antioxidant activity, it suggests possible use in the food and pharmaceutical field [5]. Fucoid component from Dictyota merttensi, Spatoglossum schroederi, and Fucus vesiculosus which contain the inflammation response for their anti-inflammation activity [88]. Lamina japonica has strong antioxidant activity due to the fucoid component in it which inhibits the increased formation of lipid peroxide in serum and liver [89] (Fig. 4). Brown algae Chnoospora minima displayed significant antiproliferative activity on cancer cell lines due to the bioactive fraction [90].

\section{Conclusion}

The review work on the phytoconstituents of brown algae makes it clear that this large group of marine algae is not only used to obtain food, fodder but is an enormous source of several secondary metabolites. This review paper holds studies of the bioactive compound of brown algae, which has many more functional properties compared to red and green algae because phaeophyta group are main representative of polysaccharide and fucoidans which are responsible for prominent biological activity. It has been noted that the types and proportions of phytoconstituents vary from species to species and depend on environmental factors. The multiple mechanisms of action promote the formation of complex bioactive compounds from brown algae, which directly enhanced their biological activity, and such activities promote many drug industries for drug production. Thus, systematic work on this group of marine algae will be helpful in the formulation of new drugs that can be used for curing several fatal diseases of a human being.

\section{Abbreviations}

UV: Ultraviolet; KDa: Kilodaltons; HIV: Human immunodeficiency virus; GCMS: Gas chromatography-mass spectrometry; RP-HPLC: Reverse phase highperformance liquid chromatography; NMR: Nuclear magnetic resonance

\section{Acknowledgements \\ We would like to thank the anonymous reviewers for their valuable comments and suggestions to improve the quality of the paper.}

\section{Authors' contributions}

ICP provided an idea for the content required for this paper. MMH planned the work in a stepwise mode. All authors have studied and approved the review article.

\section{Funding}

Not applicable

\section{Availability of data and materials}

Data and materials are available upon request.

Ethics approval and consent to participate

Not applicable
Consent for publication

Not applicable

\section{Competing interests}

The authors declared that they have no competing interests.

Received: 16 September 2020 Accepted: 29 November 2020

Published online: 09 December 2020

\section{References}

1. Kolanjinathan K, Ganesh P, Saranraj P (2014) Pharmacological importance of seaweeds: a review. World J Fish Marine Sci 6(1):01-15. https://doi.org/10. 5829/idosi.wjfms.2014.06.01.76195

2. Dawczynski C, Schubert R, Jahreis G (2007) Amino acids, fatty acids, and dietary fibre in edible seaweed products. Food Chem 103:891-899. https:// doi.org/10.1016/j.foodchem.2006.09.041

3. Fleurence J (1999) Seaweed proteins: biochemical, nutritional aspects and potential uses. Trends Food Sci Technol 10:25-28. https://doi.org/10.1016/ S0924-2244(99)00015-1

4. Anantharaman P (2002) Manual on identification of seaweed. All India coordinate project on survey and Inventorization of coastal and marine biodiversity. J Mar Biol Assoc India 29:1-9

5. Dang TT, Michael CB, lan A, Christopher JS (2018) Comparison of chemical profile and antioxidant properties of the brown algae. Int J Food Sci Technol 53:174-181. https://doi.org/10.1111/ijfs.13571

6. Gupta S, Abu-Ghannam N (2011) Bioactive potential and possible health effects of edible brown seaweeds. Trends Food Sci Technol 22:315-326. https://doi.org/10.1016/j.tifs.2011.03.011

7. Sanchez-Machado DI, López-Cervantes J, López-Hernández J, Paseiro-Losada P (2004) An HPLC method for the quantification of sterols in edible seaweeds. Biomed Chromatogr 18:183-190. https://doi.org/10.1002/bmc.316

8. Whittaker MH, Frankos VH, Wolterbeek AMP, Waalkens-Berendsen DH (2000) Effects of dietary phytosterols on cholesterol metabolism and atherosclerosis: clinical and experimental evidence. Am J Med 109:600-601. https://doi.org/10.1016/S0002-9343(00)00588-X

9. Pal A, Kamthania MC, Kumar A (2014) Bioactive compounds and properties of seaweeds- a review. OA Lib J 1:752. https://doi.org/10.4236/oalib.1100752

10. Wijesinghea JP, You JP (2012) Biological activities and potential industrial applications of fucose rich sulfated polysaccharides and fucoidans isolated from brown seaweeds: a review. Carbohydr Polym 88:13-20. https://doi.org/ 10.1016/j.carbpol.2011.12.029

11. Blunt JW, Copp BR, Munro MHG, Northcote PT, Prinsep MR (2018) Marine natural products. Nat Prod Rep 23:26-78. https://doi.org/10.1039/ c3np70117d

12. Paula JC, Pedrini AG, Pinheiro MD, Pereira RC, Teixeira VL (2001) Chemical similarity between the brown algae Dictyota cervicornis and D. pardalis (Dictyotales, Phaeophyta). Biochem Syst Ecol 29:425-427. https://doi.org/10. 1016/S0305-1978(00)00066-1 PMID: 11182491

13. Cox S, Gupta S, Abu-Ghannam N (2012) Effect of different rehydration temperatures on the moisture, content of phenolic compounds, antioxidant capacity and textural properties of edible Irish brown seaweed. LWT-Food Sci Technol 47:300-307. https://doi.org/10.1016/j.lwt.2012.01.023

14. Chakaborty K, Joseph D, Praveen NK (2015) Antioxidant activities and phenolic contents of three red seaweeds (division: Rhodophyta) harvested from the Gulf of Mannar of peninsular India. J Food Sci Technol 52:19241935. https://doi.org/10.1007/s13197-013-1189-2 PMID: 25829573

15. Dixit DC, Reddy CRK, Balar N, Suthar P, Gajaria T, Gadhavi DK (2018) Assessment of the nutritive, biochemical, antioxidant and antibacterial potential of eight tropical macro algae along Kachchh coast, India as human food supplements. J Aquat Food Prod T 27:61-79. https://doi.org/ 10.1080/10498850.2017.1396274

16. Cumashi A, Ushakova NA, Preobrazhenskaya ME, D'Incecco A, Piccoli A, Totani L (2007) A comparative study of the anti-inflammatory, anticoagulant, antiangiogenic, and antiadhesive activities of nine different fucoidans from brown seaweeds. Glycobiology 17:541-552. https://doi.org/ 10.1093/glycob/cwm014 PMID: 17296677

17. Durig J, Bruhn T, Zurborn KH, Gutensohn K, Bruhn HD, Béress L (1997) Anticoagulant fucoidan fractions from Fucus vesiculosus induce platelet activation in vitro. Thromb Res 85:79-491. https://doi.org/10.1016/500493848(97)00037-6 
18. Generalić Mekinić I, Skroza D, Šimat V, Hamed I, Čagalj M, Popović Perković Z (2019) Phenolic content of brown algae (Pheophyceae) species: extraction, identification, and quantification. Biomolecules 9(6):244. https:// doi.org/10.3390/biom9060244

19. Paul JJP, Devi SDKS (2013) Seasonal variability of Ulva species (green seaweed) in Tirunelveli region, the southeast coast of Tamil Nadu, India. Res J Marine Sci 1(1):14-17

20. Chakraborty S, Bhattacharya T (2012) Nutrient composition of marine benthic algae found in the Gulf of Kutch coastline, Gujarat, India. J Algal Biomass Util 3(1):32-38

21. Hoek C, Mann D, Jahns HM, Jahns M (1995) Algae: an introduction to phycology. Cambridge University Press

22. Krishnamurthy V, Joshi HV (1970) A check list of Indian marine algae. Central salt and Marine Chemical Research Institute Bhavnagar, Springer, p 39

23. Untawale AG, Dhargalkar VK, Agadi W (1983) A list of marine algae from IndiaNational Institute of Oceanology. Goa. Tech. Rep, p 42

24. Sahoo D, Sahoo N, Debasish (2001) Seaweeds of India coast. A.P.H Publication, New Delhi, p 283. https://doi.org/10.1007/978-90-481-2488-6

25. Oza RM, Zaidi S (2001) A revised check-list of Indian marine algae. Central salt and Marine Chemical Research Institute, Bhavnagar, p 296

26. Venkataraman K, Wafar M (2005) Coastal and marine biodiversity of India. Indian J Marine Sci 34(1):57-75

27. Jha B, Reddy CRK, Thakur MC, Rao UM (2009) The diversity and distribution of seaweeds of Gujarat coast. Springer Science and Business Media B. V, New York, p 215

28. Ragan MA, Glombitza KW (1986) Phlorotannins, brown algal polyphenols. Progr Phycol Res 4:129-241

29. Kim J, Um M, Yang H, Kim I, Lee C, Kim Y, Yoon M, Kim Y, Kim J, Cho S (2016) Method development and validation for dieckol in the standardization of phlorotannins preparations. Fish Aquatic Sci 19:1-6. https://doi.org/10.1186/s41240-016-0003-2

30. Koivikko R, Loponen J, Pihlaja K, Jormalainen V (2007) High-performance liquid chromatographic analysis of phlorotannins from the brown alga Fucus vesiculosus. Phytochem Anal 18:326-332. https://doi.org/10.1002/pca. 986 PMID: 17623367

31. Saravana PS, Getachew AT, Cho YJ, Choi JH, Park YB, Woo HC, Chun BS (2017) Influence of co-solvents on fucoxanthin and phlorotannin recovery from brown seaweed using supercritical CO2. J Supercrit Fluids 120:295303. https://doi.org/10.1016/j.supflu.2016.05.037

32. SanchezCamargo AP, Montero L, Cifuentes A, Herrero M, Ibáñez E (2016) Application of Hansen solubility approach for the subcritical and supercritical selective extraction of phlorotannins from Cystoseira abiesmarina. RSC Adv 6:94884-94895. https://doi.org/10.1039/C6RA16862K

33. Okada Y, Ishimaru A, Suzuki R, Okuyama T (2004) A new phloroglucinol derivative from the brown alga Eisenia bicyclis: potential for the effective treatment of diabetic complications. J Nat Prod 67:103-105. https://doi.org/ 10.1021/np030323j PMID: 14738398

34. Wijesekara I, Yoon NY, Kim SK (2010) Phlorotannins from Ecklonia cava (Phaeophyceae): biological activities and potential health benefits. BioFactors 36(6):408-414. https://doi.org/10.1002/biof.114 PMID: 20803523

35. Young $\mathrm{MH}$, Jong SB, Jin $\mathrm{WH}$, Nam HL (2007) Isolation of a new phlorotannin, fucodiphlorethol G, from a brown alga Ecklonia cava. Bull Kor Chem Soc 28:1595-1597. https://doi.org/10.5012/bkcs.2007.28.9.1595

36. Yoon NY, Chung HY, Kim HR, Choi JS (2008) Acetyl- and butyrylcholinesterase inhibitory activities of sterols and phlorotannins from Ecklonia stolonifera. Fisheries Sci 74:200. https://doi.org/10.1111/j.14442906.2007.01511.x

37. Shibata T, Yamaguchi K, Nagayama K, Kawaguchi S, Nakamura T (2012) Inhibitory activity of brown algal phlorotannins against glycosidases from the viscera of the turban shell Turbo cornutus. Eur J Phycol 37:493-500. https://doi.org/10.1017/S0967026202003918

38. Nagayama K, Shibata T, Fujimoto K, Honjo T, Nakamura T (2003) Algicidal effect of phlorotannins from the brown alga Ecklonia kurome on red tide microalgae. Aquaculture 218:601-611. https://doi.org/10.1016/S00448486(02)00255-7

39. Jung HA, Hyun SK, Kim HR, Choi JS (2006) Angiotensin converting enzyme I inhibitory activity of phlorotannins from Ecklonia stolonifera. Fisheries Sci 72: 1292-1299. https://doi.org/10.1111/j.1444-2906.2006.01288.x

40. Joe MJ, Kim SN, Choi HY, Shin WS, Park GM, Kang DW, Kim YK (2006) The inhibitory effects of eckol and dieckol from Ecklonia stolonifera on the expression of matrix metalloproteinase-1 in human dermal fibroblasts. Biol
Pharm Bull 29:1735-1739. https://doi.org/10.1248/bpb.29.1735 PMID: 16880634

41. Sugiura Y, Matsuda K, Yamada Y, Nishikawa M, Shoiya K, Katsuzaki H, Imai K, Amano H (2006) Isolation of a new anti-allergic phlorotannin, phlorofucofuroeckol-b, from an edible brown alga Eisenia arborea. Biosci. Biotechnol. Biochem 70(11):2807-2811. https://doi.org/10.1271/bbb.60417

42. Koch M, Gregson RP (1984) Brominated phlorethols and nonhalogenated phlorotannins from the brown alga Cystophora congesta. Phytochemistry 23 2633-2637. https://doi.org/10.1016/S0031-9422(00)84115-1

43. Gaurav R, Barry F, Nissreen AG (2016) Identification and characterization of phenolic antioxidant compounds from Brown Irish seaweed Himanthalia elongata using LC-DAD-ESI-MS/M. Innov Food Sci Emerg Technol 37:261268. https://doi.org/10.1016/j.ifset.2016.02.005

44. Heo SJ, Hwang JY, Choi I, Han JS, Kim HJ, Jeon YJ (2009) Diphlorethohydroxycarmalol isolated from Ishige okamurae, a brown algae, a potent -glucosidase and -amylase inhibitor, alleviates postprandial hyperglycemia in diabetic mice. Eur J Pharmacol 615:252-256. https://doi. org/10.1007/s10811-008-9320-x

45. Afsaneh Y, Alireza G, Ladan D (2016) Chemical constituents and biological activities of two Iranian Cystoseira species. Res Pharm Sci 11(4):311-317. https://doi.org/10.4103/1735-5362.189307 PMID: 27651811

46. Ferreres F, Lopes G, Gil-Izquierdo A, Andrade BC, Sousa Mouga T, Valentão P (2012) Phlorotannin extracts from fucales characterized by HPLC-DAD-ESIMSn: approaches to hyaluronidase inhibitory capacity and antioxidant properties. Mar Drugs 10:2766-2781. https://doi.org/10.3390/2Fmd10122766 PMID: 23222802

47. Piironen V, Toivo J, Puupponen-Pimia R, Lampi AM (2003) Plant sterols in vegetables, fruits and berries. J Sci Food Agric 83:330-337. https://doi.org/ 10.1002/jsfa.1316

48. Lagarda MJ, Garcia-Llatas G, Farre R (2006) Analysis of phytosterols in foods. J Pharm Biomed Anal 41:1486-1496. https://doi.org/10.1016/j.jpba.2006.02. 052

49. Abidi SL (2001) Chromatographic analysis of plant sterols in foods and vegetable oils. J Chromatogr 935:173-201. https://doi.org/10.1016/S00219673(01)00946-3 PMID:11762774

50. Rocco A, Fanali S (2009) Analysis of phytosterols in extra-virgin olive oil by nano-liquid chromatography. J Chromatogr A 1216:7173-7178. https://doi. org/10.1016/j.chroma.2009.03.081 PMID:19386314

51. Gihan AS, Essam AS (2014) Terpenes and sterols composition of marine Brown algae Padina pavonica (Dictyotales) and Hormophysa triquetra (Fucales). Int JPharma Phyto Res 6(4):894-900

52. Murugan K, lyer W (2014) Antioxidant activity and gas chromatographicmass spectrometric analysis of extracts of the marine algae, Caulerpa peltata and Padina Gymnospora. Indian J Pharm Sci 76(6):548-552. https://doi.org/ 10.4103/0250-474X.147242 PMID:25593390

53. Caamal FE, Moo PR, Freile PY, Robledo D (2014) Cytotoxic and antiproliferative constituents from Dictyota ciliolata, Padina sanctae-crucis and Turbinaria tricostata. Pharm Biol 27:1-5. https://doi.org/10.3109/ 13880209.2014.886273 PMID: 24863279

54. Ayyad SE, Sowellim SZ, El-Hosini MS, Abo-Atia A (2003) The structural determination of a new steroidal metabolite from the brown alga Sargassum asperifolium. Zeitschrift fur Naturforschung C. J Biosci 58:333-336. https://doi.org/10.1515/znc-2003-5-607

55. Xiao HX, Zhi QY, Gong KL (2013) Preparation of phytosterols and phytol from edible marine algae by microwave-assisted extraction and high-speed counter-current chromatography. Sep Purif Technol 104:284-289. https:// doi.org/10.1016/j.seppur.2012.11.032

56. Bouzidi N, Viano Y, Ortalo MA, Seridi H, Alliche Z, Daghbouche Y, Culioli G, Hattab M (2014) Sterols from the brown alga Cystoseira foeniculacea: degradation of fucosterol into saringosterol epimers. Arab J Chem:553. https://doi.org/10.1016/j.arabjc.2014.11.004

57. Aires A (2017) Phenolics in foods: extraction, analysis and measurements. In phenolic compounds-natural sources, importance and applicationsIn Tech pp, pp 61-88. https://doi.org/10.5772/66889

58. Yajing $L$, Xiaoting F, Delin D, Xiaoyong $L$, Jiachao X, Xin G (2017) Extraction and identification of phlorotannins from the brown alga, Sargassum fusiforme. Mar Drugs 15:49. https://doi.org/10.3390/md15020049 PMID: 28230766

59. Cruces E, Rojas Y, Ramire KE, Atala C, Lopez-Alarcon LE, Gomez I (2016) Comparison of different techniques for the preservation and extraction of phlorotannins in the kelp Lessonia spicata (Phaeophyceae): assays of DPPH, 
ORAC-PGR, and ORAC-FL as testing methods. J Appl Phycol 28:573-580. https://doi.org/10.1007/s10811-015-0602-9

60. Sanjeewa KA, Kim EA, Son KT, Jeon YJ (2016) Bioactive properties and potentials cosmeceutical applications of phlorotannins isolated from brown seaweeds: a review. J Photochem Photobiol B 162:100-105. https://doi.org/ 10.1016/j.jphotobiol.2016.06.027

61. Li YX, Wijesekara I, Li Y, Kim SK (2011) Phlorotannins as bioactive agents from brown algae. Process Biochem 46(12):2219-2224. https://doi.org/10. 1016/j.procbio.2011.09.015

62. Thomas NV, Kim SK (2011) Potential pharmacological applications of polyphenolic derivates from marine brown algae. 32:325-335. https://doi. org/10.1016/j.etap.2011.09.004

63. Sudha G, Balasundaram A (2018) Analysis of bioactive compounds in Padina pavonica using HPLC, UV-VIS and FTIR techniques. J Pharmacog Phytochem 7(3):3192-3195

64. Rajamani K, Somasundaram ST (2018) Polyphenols from brown alga, Padina boergesenii (Allendar \& Kraft) decelerates renal cancer growth involving cell cycle arrest and induction of apoptosis in renal carcinoma cells. Environ Toxicol:1-8. https://doi.org/10.1002/tox.22619

65. Sabeena KH, Jacobsen C (2013) Phenolic compounds and antioxidant activities of selected species of seaweeds from Danish coast. Food Chem 138:1670-1681. https://doi.org/10.1016/j.foodchem.2012.10.078 PMID: 23411297

66. El Gamal AA (2010) Biological importance of marine algae. Saudi Pharmaceut J 18(1):1-25. https://doi.org/10.1016/j.jsps.2009.12.001

67. Capon Rl, Barrow RA, Rochfort S, Jobling M, Skene C, Larcey E, Gill IH, Friedel T, Wadsworth D (1998) Marine nematodes: tetrahydrofuran from a southern australian brown alga.Notheia Anomala. Tetrahdron 54:2227-2242

68. Bennamara A, Abourrichi A, Berrada M, M'hamed C, Chaib N, Boudouma M, Garneau XF (1999) Methoxybifur-carenone: an antifungal and antibacterial meroditerpenoid from the brown alga Cystoseira tamariscifolia. Phytochemistry 52:37-40

69. Kim YC, An RB, Yoon NY, Nam TJ, Choi JS (2005) Hepatoprotective constituents of the edible brown alga Ecklonia stolonifera on tacrineinduced cytotoxicity in hep G2 cells. Arch Pharm Res 28(12):1376

70. Lee YS, Shin KH, Kim BK, Lee S (2004) Anti-diabetic activities of fucosterol from Pelvetia siliquosa. Arch Pharm Res 27(11):1120-1122

71. Suzuki M, Yamada H, Kurata K (2002) Dictyterpenoids a and B, two novel Diterpenoids with feeding-deterrent activity from the Brown alga Dilophus o kamurae. J Nat Prod 65(2):121-125. https://doi.org/10.1021/np010234b

72. Sugiura Y, Matsuda K, Yamada Y, Nishikawa M, Shioya K, Katsuzaki H (2007) Anti-allergic phlorotannins from the edible brown alga, Eisenia Arborea. Food Sci Technol Res 13:54-60

73. Jung HA, Hyun SK, Kim HR, Choi JS (2006) Angiotensin-converting enzyme I inhibitory activity of phlorotannins from Ecklonia stolonifera. Fish Sci 72(6): 1292-1299. https://doi.org/10.1111/j.1444-2906.2006.01288.x

74. Waghmode AV, Khilare CJ (2018) RP-HPLC profile of major phenolics from brown marine macro algae. J Appl Pharm 10(2):1-5. https://doi.org/10.4172/ $1920-4159.1000262$

75. Natrah FMI, Harah M, Japar Sidik B, Izzatul NS, Syahidah A (2015) Antibacterial activites of selected seaweed and seagrass from Port Dickson coastal water against different aquaculture pathogens. Sains Malaysiana 44(9):1269-1273. https://doi.org/10.17576/ism-2015-4409-08

76. Senthilkumar K, Manivasagan P, Venkatesan J, Kim SK (2013) Brown seaweed fucoidan: biological activity and apoptosis, growth signaling mechanism in cancer. Int J Biol Macromol 60:366-374. https://doi.org/10.1016/j.jibiomac. 2013.06.030 PMID: 23817097

77. Kang Y, Zhi JW, Dongsheng $X$, Xue S, Wenge Y, Xiaodong Z, Nianjun $X$ (2017) Characterization and potential antitumor activity of polysaccharide from Gracilariopsis lemaneiformis. Drugs 15:100. https://doi.org/10.3390/ 2Fmd15040100 PMID: 28353631

78. Corona G, Coman MM, Spencer JPE, Rowland I (2014) Digested and fermented seaweed phlorotannins reduce DNA damage and inhibit growth of HT-29 colon cancer cells. Proc Nutr Soc 73:31. https://doi.org/10.1017/ S0029665114000457

79. Antunes EM, Anthonia FA, Maynard TC, Jameel F, Michael GK, Catherine EV, Denver TH, John JB, Denzil RB (2011) Identification and in vitro antiesophageal cancer activity of a series of halogenated monoterpenes isolated from the south African seaweeds Plocamium suhrii and Plocamium cornutum. Phytochemistry 72:769-772. https://doi.org/10.1016/j.phytochem. 2011.02.003 PMID:121392811
80. Nishide E, Uchida H (2003) Effects of Ulva powder on the ingestion and excretion of cholesterol in rats. In: Chapman ARO, Anderson RJ, Vreeland VJ, Davison IR (eds) Proceedings of the 17th international seaweed symposium. Oxford University Press, Oxford, pp 165-168

81. Crockett SL, Wenzig EM, Kunert O, Bauer R (2008) Anti-inflammatory phloroglucinol derivatives from Hypericum empetrifolium. Phytochem Lett 1: 37-43. https://doi.org/10.1016/2Fj.phytol.2007.12.003 PMID: 21151761

82. Daikonya A, Katsuki S, Wu JB, Kitanaka S (2002) Anti-allergic agents from natural sources (4): anti-allergic activity of new phloroglucinol derivatives from Mallotus philippensis (Euphorbiaceae). Chem Pharm Bull(Tokyo) 50: 1566-1569. https://doi.org/10.1248/cpb.50.1566 PMID:12499591

83. Kim MM, Kim SK (2010) Effect of phloroglucinol on oxidative stress and inflammation. Food Chem Toxicol 48:2925-2933. https://doi.org/10.1016/j. fct.2010.07.029 PMID: 20667461

84. Boopathy N, Kathiresan K (2010) Anticancer drugs from marine flora: an overview. J Oncol 2010:18. https://doi.org/10.1155/2010/214186

85. Vo TS, Kim SK (2010) Potential anti-HIV agents from marine resources: an overview. Mar Drugs 8:2871-2892. https://doi.org/10.3390/md8122871 PMID: 21339954

86. Wang W, Wang SX, Guan HS (2012) The antiviral activities and mechanisms of marine polysaccharides: an overview. Mar Drugs 10:2795-2816. https:// doi.org/10.3390/md10122795 PMID: 23235354

87. Jose GM, Anitha R, Muraleedhara K (2015) Antioxidant and antimitotic activities of sulfated polysaccharide from marine brown algae Padina tetrastromatica. J Phytology 7:39-51. https://doi.org/10.19071/jp.2015.v7.2921

88. Kang SM, Kim KN, Lee $S H$, Ahn G, Cha SH, Kim AD, Yang XD, Kang MC, Jeon YJ (2011) Anti-inflammatory activity of polysaccharide purified from AMGassistant extract of Ecklonia cava in LPS-stimulated RAW264.7 macrophages. Carbohydr Polym 85:80-85. https://doi.org/10.1016/j.carbpol.2011.01.052

89. Li DY, Xu RY, Zhou WZ, Sheng XB, Yang AY, Cheng JL (2002) Effects of fucoidan extracted from brown seaweed on lipid peroxidation in mice. Acta Nutrimenta Sinica 24:389-392. https://doi.org/10.3390/md17100591

90. Parveen S, Nadumane VK (2020) Anti-angiogenesis and apoptogenic potential of the brown marine alga, Chnoospora minima. Future J Pharmaceutical Sci 6(1):1-14. https://doi.org/10.1186/s43094-020-00039-9

\section{Publisher's Note}

Springer Nature remains neutral with regard to jurisdictional claims in published maps and institutional affiliations.

\section{Submit your manuscript to a SpringerOpen ${ }^{\circ}$ journal and benefit from:}

- Convenient online submission

- Rigorous peer review

- Open access: articles freely available online

- High visibility within the field

- Retaining the copyright to your article

Submit your next manuscript at $\boldsymbol{\triangleright}$ springeropen.com 